Journal of Advanced Research in Applied

Sciences and Engineering Technology

Journal homepage: www.akademiabaru.com/araset.html

ISSN: 2462-1943

\title{
Forensic to the Reinforced Concrete (RC) Structures at Library
}

\author{
Tang Hing Kwong ${ }^{1,}{ }^{*}$, Rudy Tawie ${ }^{2}$, Siti Rozana Romali ${ }^{1}$ \\ Department of Civil Engineering, Politeknik Kuching Sarawak, KM 22, Jalan Matang, 93050, Kuching Sarawak, Malaysia \\ Centre of Engineering Studies, Universiti Teknologi MARA, 94300 Kota Samarahan, Malaysia
}

\begin{abstract}
This Forensic project has been proposed to investigate the reinforced concrete structure defect at library. There were found 65 points cracks and 20 points spalling in library such as only at reinforced concrete beam and slab part in first floor. The total of cracks which crack width less than $0.25 \mathrm{~mm}$ is 63 points and the crack width between $0.25 \mathrm{~mm}$ to $5.00 \mathrm{~mm}$ is 2 points only. These cracks had categorized as fine cracks because the crack width not more than $5 \mathrm{~mm}$. There was 21 samples Rebound Hammer test was random measured the existing concrete compressive strength of critical structures which six samples at beams, six samples at slabs, six samples at columns and three samples at staircase in library. The Rebound Hammer test shown that average mid-point strength at beam is $33 \mathrm{~N} / \mathrm{mm}^{2}$, slab is $25 \mathrm{~N} / \mathrm{mm}^{2}$, column is $38 \mathrm{~N} / \mathrm{mm}^{2}$ and staircase is $37 \mathrm{~N} / \mathrm{mm}^{2}$. Based on the Eurocode 2, the minimum grade concrete required is $25 \mathrm{~N} / \mathrm{mm}^{2}$ to do the design for reinforced concrete structures, which all the existing concrete strength were achieved the minimum concrete strength. Finally, the Orion software are used to analysis and determine the size of steel reinforcement, the design found the required bar size of steel reinforcement at the middle span or continuous support is 2 T16 \& $2 \mathrm{~T} 25$ or $2 \mathrm{~T} 20$ \& $2 \mathrm{~T} 25$ but the existing steel reinforcement is $2 \mathrm{~T} 12$ and $2 \mathrm{~T} 20$ which the existing steel reinforcement could not be sustained the big loading that applied on the library.
\end{abstract}

\section{Keywords:}

Building forensic; Reinforced Concrete

(RC), Rebound Hammer Test, steel

reinforcement, Orion Software.

Copyright @ 2020 PENERBIT AKADEMIA BARU - All rights reserved

\section{Introduction}

Cracks are one kind of universal problem of concrete construction as it affects the building artistic and it also destroys the structures integrity, affects the structure safety even reduce the durability of structure [1]. Some researchers already worked on related topics of causes and remedies of cracks such as an experimental study of crack patterns on reinforced concrete beam found that the different types, nature and effects of cracks in concrete structure are caused by overloading, corrosion, shrinkage or poor workmanship [2]. Causes and evaluation of cracks done in concrete structure research can be used by different technique like Crack Compactor and by Ultrasonic Testing [3]. Research for the crack width evaluation for flexural reinforced concrete members found that the reinforcement detailing or bars distribution is an important factor affecting the crack width and building code equation should limit the value of the mean steel stress as given by Eurocode equation

\footnotetext{
* Corresponding author tanghingkwong@gmail.com
}

https://doi.org/10.37934/araset.19.1.614 
to overcome the underestimated values obtained in the case of sections having low steel ratio [4]. Case study on identification, evaluation \& repair of cracks in concrete structures found that the repair materials and repair techniques are different, depending upon the forms of cracks according to their positions in structure. Some types of cracks seriously need attention as they are structurally hazardous [5]. A cases study structural investigation into the causes of cracks in building and solutions found that an engineer should have a sound knowledge of causes, effect and types of cracks likely to occur from the behavior of construction materials and construction techniques, which will enable him, proffer the appropriate prevention and remedial measures [6].

However, forensic investigation for sustainability issues in structure found that forensic engineering is the professional engineering investigation works for the structural failure [7]. Apart from judicial or professional necessity, forensic engineering is a systematic study and interdisciplinary in structure failure analysis [8]. According to Lim, building forensic works not only do the visual inspection and materials test but re-evaluated structurally to determine the design adequacy and functionality for use based to the design code BS8110 and loading criteria BS6399 [9]. Hence for better understanding building forensic, this research will be divided into three part such as building defect/ crack inspection by using crack gauge monitoring, strength concrete determination by using rebound hammer test and re-evaluated reinforced concrete structures by using Orion software. Rebound hammer test are used because there are simple and effective method to estimate the compressive strength of concrete [10-11]. It also useful in finding the early strength of concrete [12]. Orion are used for structural integrity and capacity evaluations because there are practical tools and fast solutions in analyses and design for the reinforced concrete structures building based on different building code [13-15].

\section{Methodology}

Reinforced concrete structures defect/ crack had been investigated at library. A crack gauges are used to monitor horizontal or vertical movement across a crack on a flat reinforced concrete surface as shown in Figure 1. Then, a crack width ruler or transparent gauge are used to determine the width of the crack based on the specified width / range of graded lines [16-18].

Rebound Hammer Test was tested to determine the strength of concrete in library at several reinforced concrete structure parts such as slab, beam, column and staircase to get the average reading of existing concrete strength. Figure 2 shown the procedure of Rebound Hammer Test.

Information from the as-built details and existing concrete strength result was reliably used to re-evaluate the reinforced concrete structure. Design was checked against two limit state conditions, such as Serviceability Limit State (SLS) and Ultimate Limit State (ULS). Structural capacity was computed by using Orion software and checked against the maximum load effects under ULS. Structural design, load combinations and load intensities are in accordance with BS8110 or Eurocode 2 and BS6399 [19-21]. For the library or reading rooms with book storage, minimum imposed floor load or uniformity distributed load was $4.0 \mathrm{KN} / \mathrm{m}^{2}$ and air condition room or plant rooms, fan rooms was $7.5 \mathrm{KN} / \mathrm{m}^{2}$ [22]. Figure 3 until 5 shown the procedure of design structure library by using Orion software [23]. 


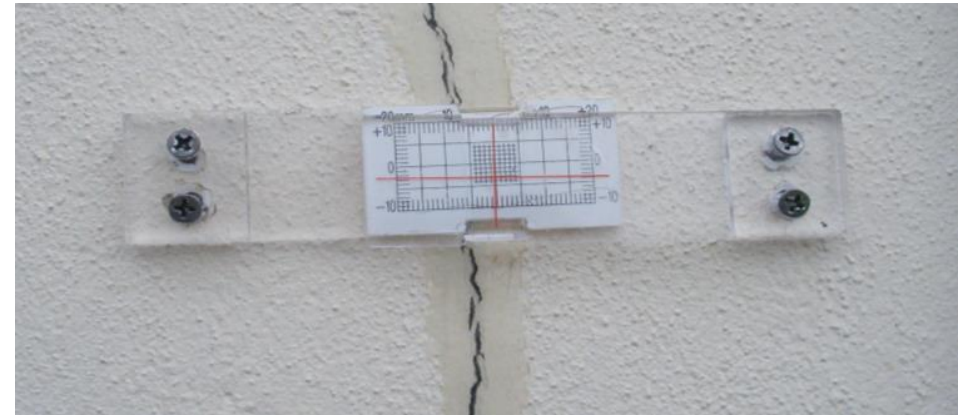

Fig. 1. Standard Crack Gauge to monitor building crack

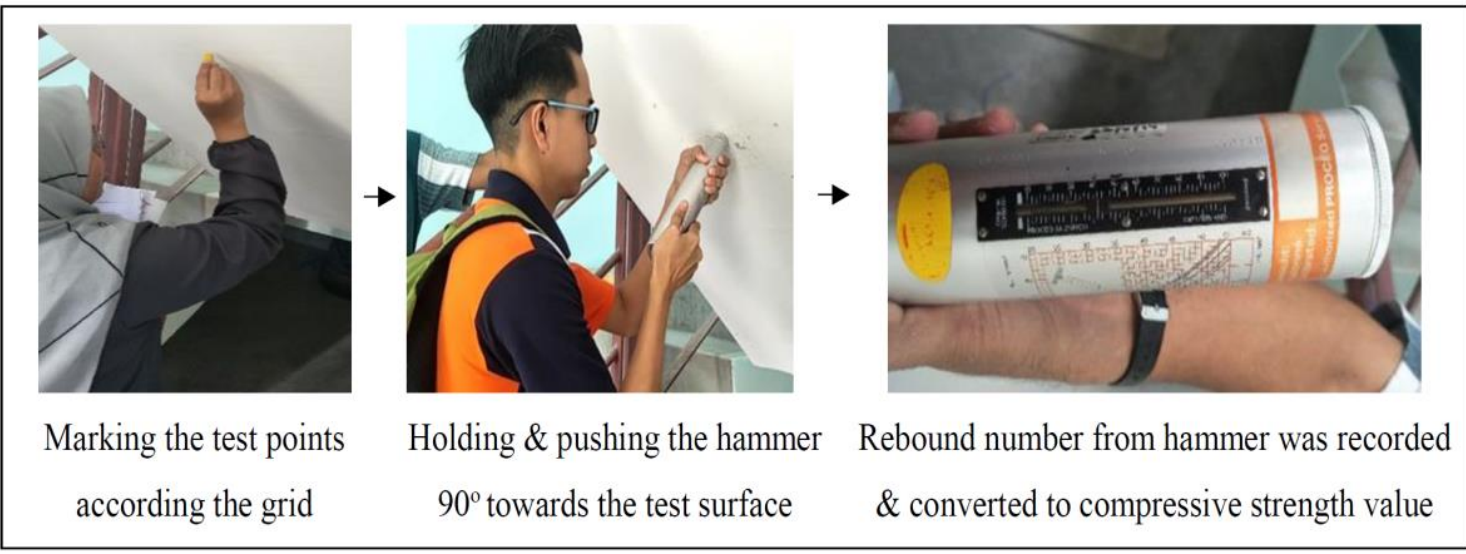

Fig. 2. Rebound Hammer Test procedures

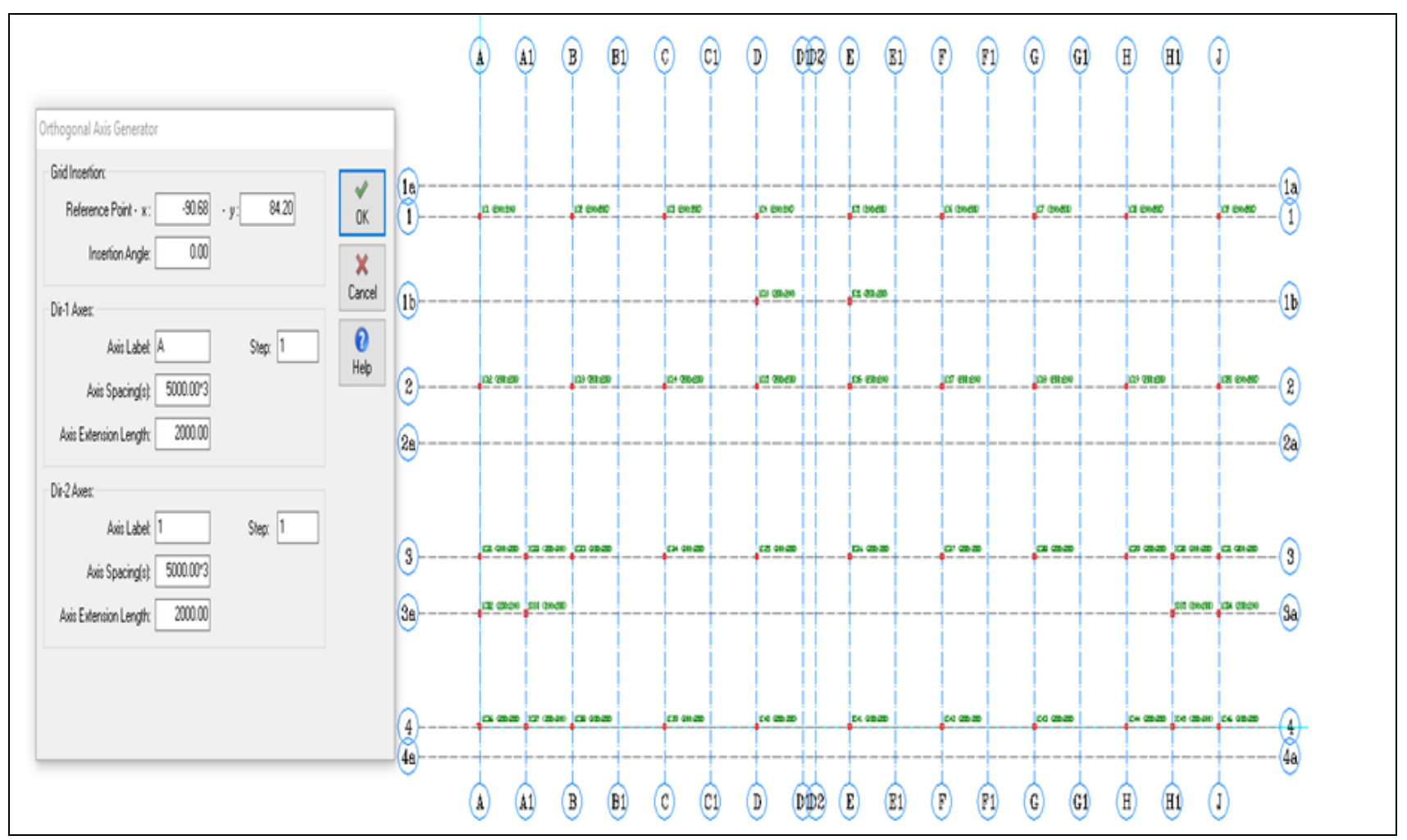

Fig. 3. Orthogonal axis generator 


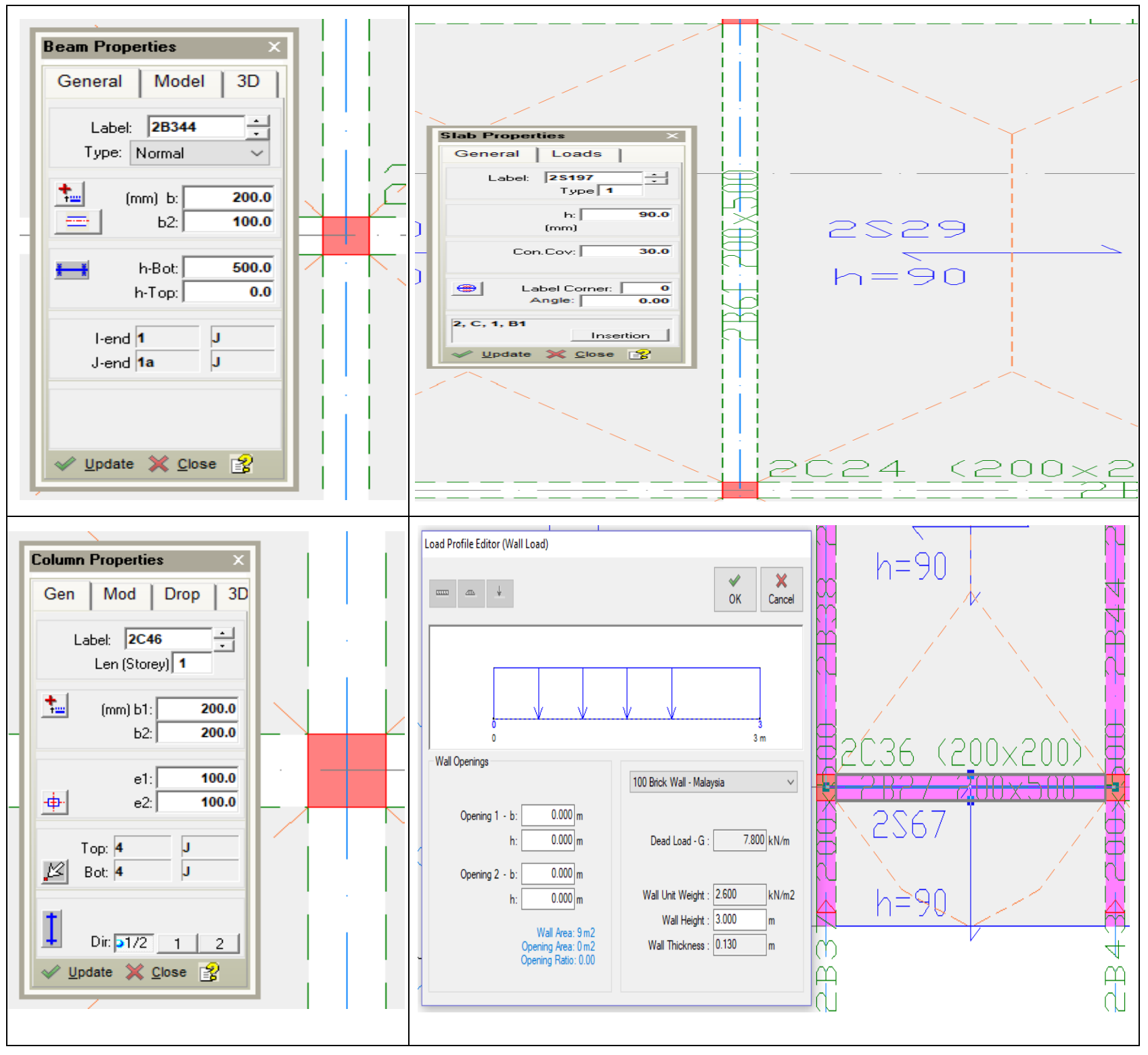

Fig. 4. Creation for Beam, Column, Slab \& Wall

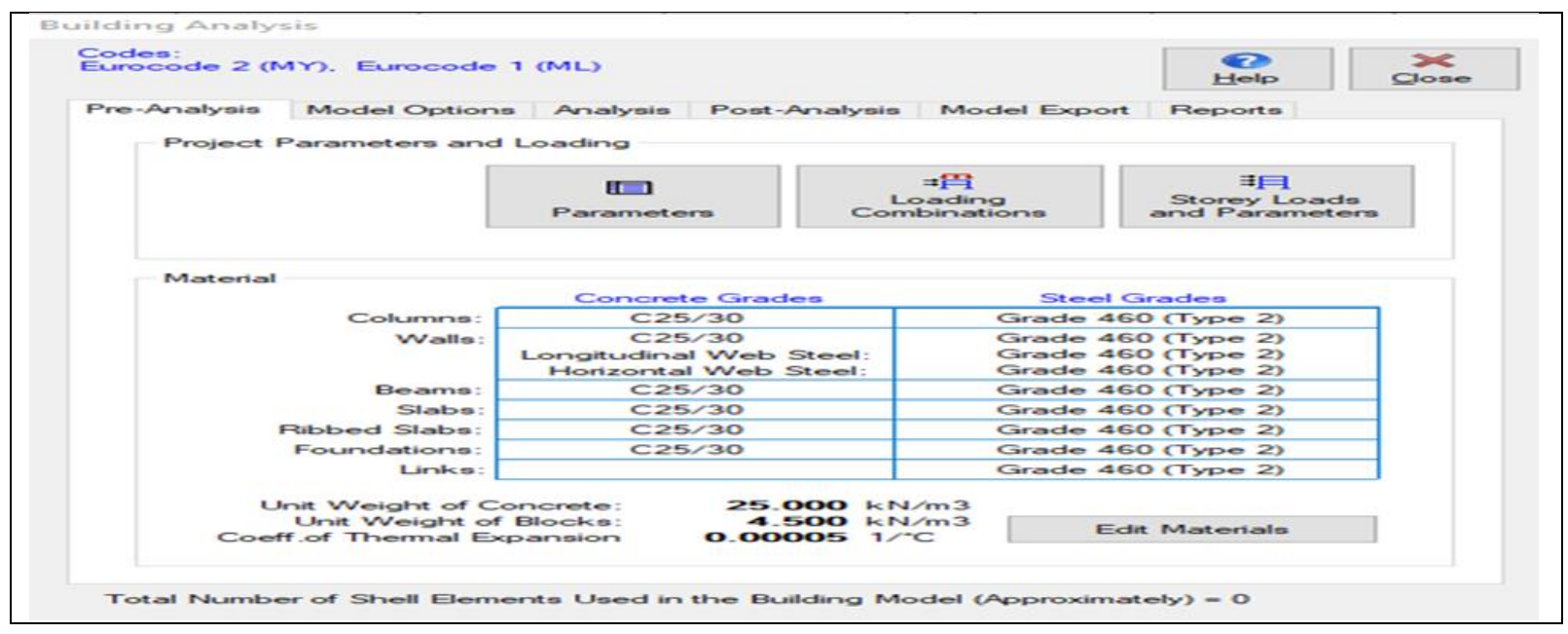

Fig. 5. Building structural analysis 


\section{Results}

\subsection{Building Defect / Crack}

Based on the building crack monitoring/ observation, the cracks at the library structures were passive crack. This is because when there had loading in it, the structure started crack. While, when the loading removed, the crack width was statics. Based on the type of concrete crack shown as Figure 6 and the crack mapping shown as Figure 7, the quantity of crack where crack width less than $0.25 \mathrm{~mm}$ is the most, which is 63 points occurred only at beam \& slab. The quantity of crack width between $0.25 \mathrm{~mm}$ to $5 \mathrm{~mm}$ is only 2 points. Moreover, the quantity of spalling concrete is 20 points. In general, the overall structure was found in safe condition without apply service/ live / imposed load at library. Therefore, detail material test is required to check the strength of concrete and size of steel reinforcement based on the Serviceability Limit State (SLS) design.

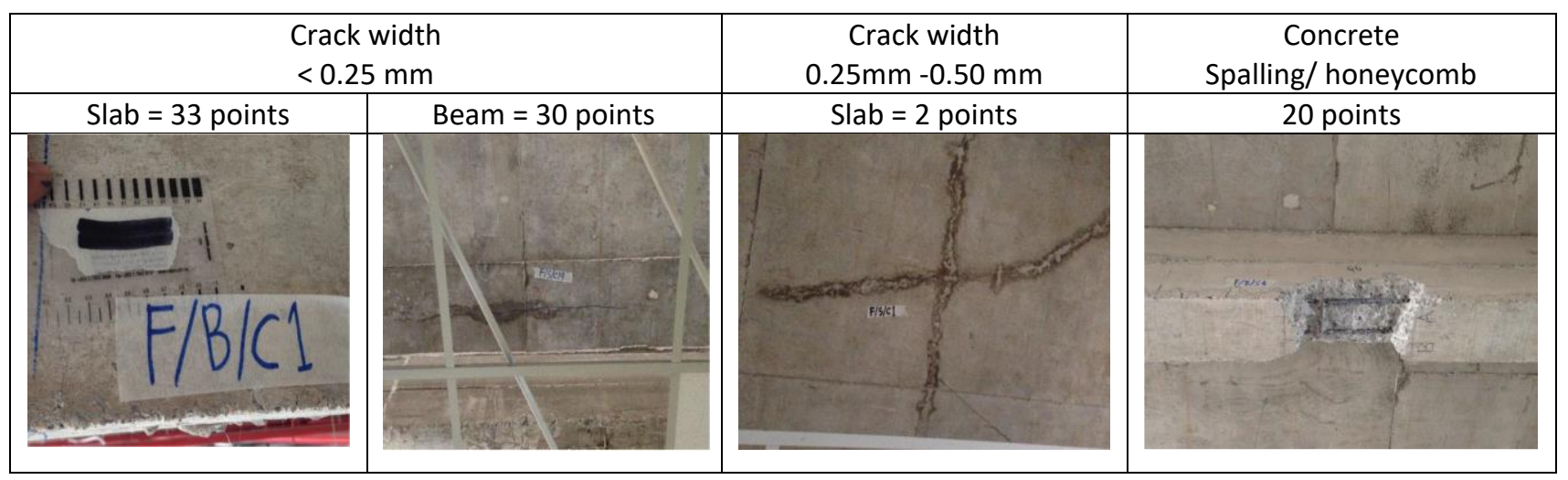

Fig. 6. Type of the concrete defects at the slab \& beam

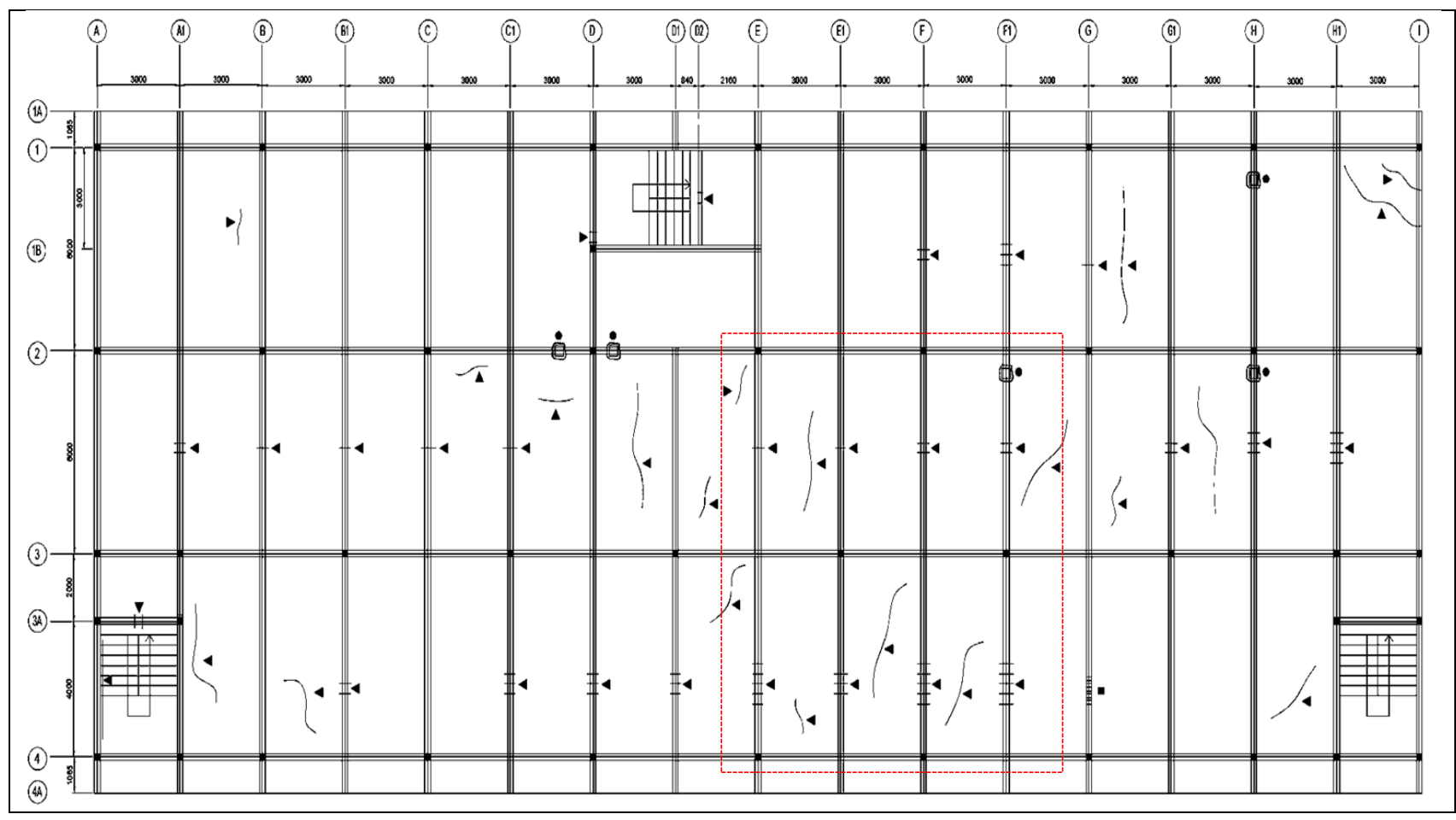

Fig. 7. Library Defect/ Crack Mapping at First Floor Plan (Soffit) 


\subsection{Material Test Results}

The rebound hammer test result in Table 1 obtained showed that the average concrete strength at beam was $33 \mathrm{~N} / \mathrm{mm}^{2}$, slab was $25 \mathrm{~N} / \mathrm{mm}^{2}$, column was $38 \mathrm{~N} / \mathrm{mm}^{2}$ and staircase was $37 \mathrm{~N} / \mathrm{mm}^{2}$. Therefore, all the existing concrete strength are achieved the minimum grade concrete required is $25 \mathrm{~N} / \mathrm{mm}^{2}$ based on the building code design. However, the existing concrete strength for the slab are required to do the detail check by core coring test.

\section{Table 1}

Summary Result for the Rebound Hammer Test

\begin{tabular}{|c|c|c|c|c|c|c|c|c|c|c|c|c|c|c|c|c|c|c|c|c|c|}
\hline \multirow{2}{*}{$\begin{array}{c}\text { Location of } \\
\text { Test }\end{array}$} & \multicolumn{6}{|c|}{ Beam } & \multicolumn{6}{|c|}{ Slab } & \multicolumn{6}{|c|}{ Column } & \multicolumn{3}{|c|}{ Staircase } \\
\hline & $E / 3-4$ & $E / 3-4$ & $E / 3-4$ & H1/2-3 & $H 1 / 2.3$ & $H 1 / 2.3$ & \begin{tabular}{|c|}
$D \cdot D 1 /$ \\
$2 \cdot 3$
\end{tabular} & $\begin{array}{c}\text { D.D11 } \\
2.3\end{array}$ & $\begin{array}{c}E 1-F I \\
3-4\end{array}$ & $\begin{array}{c}E 1-F \mid \\
3-4\end{array}$ & \begin{tabular}{|l|} 
G1.HI \\
$2 \cdot 3$
\end{tabular} & \begin{tabular}{|c|} 
G1-HI \\
$2 \cdot 3$
\end{tabular} & $|A 1 / 3 A|$ & $E / 2$ & $E / 4$ & $\mathrm{E} 1 / 3$ & F/4 & H/2 & \begin{tabular}{|c|}
$A-A 1 /$ \\
$3 A-4$
\end{tabular} & \begin{tabular}{|l|}
$D-D 21$ \\
$1-1 B$ \\
\end{tabular} & H1-II \\
\hline $\begin{array}{l}\text { Position of } \\
\text { Hammer }\end{array}$ & 0 & $+90^{\circ}$ & $.90^{\circ}$ & 0 & $+90^{\circ}$ & $-90^{\circ}$ & $+90^{\circ}$ & $.90^{\circ}$ & $+90^{\circ}$ & $.90^{\circ}$ & $+90^{\circ}$ & $-90^{\circ}$ & 0 & 0 & 0 & 0 & 0 & 0 & $+45^{\circ}$ & $+45^{\circ}$ & $+45^{\circ}$ \\
\hline \multirow{12}{*}{$\begin{array}{c}\text { Hammer } \\
\text { Readings } \\
\text { (stike through } \\
\text { highest \& lowest } \\
\text { reading and any } \\
\text { other than } \\
\text { obvious error) }\end{array}$} & 36 & 46 & 32 & jo & 40 & 04 & 50 & 25 & 34 & 34 & 35 & 34 & 40 & 45 & 48 & 45 & 41 & 44 & 43 & 43 & 47 \\
\hline & 44 & 44 & 34 & 45 & 47 & 36 & 31 & 27 & 42 & 30 & 37 & 33 & 43 & 44 & 44 & 45 & 44 & 43 & 44 & 46 & 45 \\
\hline & 42 & 44 & 34 & 45 & 46 & 34 & 42 & 31 & 34 & 25 & 35 & 31 & 45 & 41 & 46 & 45 & 44 & 44 & 45 & 37 & 44 \\
\hline & 44 & 45 & 39 & 38 & 40 & 35 & 37 & 34 & 40 & 30 & 37 & 25 & 43 & 36 & 37 & 44 & 36 & 36 & 42 & 43 & 45 \\
\hline & 42 & 47 & 37 & 39 & 46 & 35 & 40 & 31 & 40 & 35 & 43 & 32 & 43 & 36 & 44 & 46 & 44 & 45 & 44 & 44 & 38 \\
\hline & 36 & 38 & 35 & 38 & 44 & 38 & 41 & 29 & 39 & 27 & 40 & 25 & 42 & 43 & 44 & 46 & 44 & 43 & 45 & 46 & 43 \\
\hline & 37 & 44 & 36 & 40 & 42 & 38 & 36 & 33 & 34 & 35 & 34 & 34 & 43 & 38 & 38 & 38 & 46 & 46 & 45 & 44 & 46 \\
\hline & 37 & 43 & 39 & 38 & 43 & 37 & 45 & 34 & 42 & 34 & 40 & 28 & 44 & 44 & 38 & 35 & 44 & 44 & 44 & 45 & 45 \\
\hline & 39 & 44 & 31 & 44 & 47 & 34 & 34 & 33 & 42 & 36 & 42 & 34 & 44 & 44 & 43 & 46 & 45 & 45 & 47 & 46 & 42 \\
\hline & 44 & 46 & 35 & 42 & 45 & 34 & 32 & 30 & 36 & 30 & 45 & 28 & 44 & 39 & 40 & 42 & 39 & 38 & 45 & 44 & 38 \\
\hline & 35 & 38 & 33 & 40 & 41 & 36 & 40 & 28 & 35 & 33 & 36 & 26 & 42 & 45 & 40 & 39 & 37 & 44 & 48 & 46 & 44 \\
\hline & 36 & 39 & 34 & 43 & 42 & $J T$ & 33 & 34 & 42 & 34 & 44 & 25 & 37 & 36 & 44 & 41 & 37 & 45 & 45 & 45 & 43 \\
\hline $\begin{array}{l}\text { Average of } \\
\text { remaining readings }\end{array}$ & 39 & 43 & 35 & 41 & 44 & 36 & 37 & 31 & 38 & 32 & 39 & 30 & 43 & 41 & 42 & 43 & 42 & 43 & 45 & 44 & 43 \\
\hline $\begin{array}{l}\text { Compressive strength } \\
\text { Graph, } \mathrm{f}_{\alpha}\left(\mathrm{N}^{2} \mathrm{~mm}^{2}\right)\end{array}$ & 38.0 & 39.0 & 37.0 & 42.0 & 41.0 & 39.0 & 28.0 & 30.0 & 30.0 & 32.0 & 30.5 & 29.0 & 46.0 & 42.0 & 44.0 & 46.0 & 44.0 & 46.0 & 45.0 & 43.0 & 41.0 \\
\hline \begin{tabular}{|l|} 
Field correction factor \\
\end{tabular} & 0.85 & 0.85 & 0.85 & 0.85 & 0.85 & 0.85 & 0.85 & 0.85 & 0.85 & 0.85 & 0.85 & 0.85 & 0.85 & 0.85 & 0.85 & 0.85 & 0.85 & 0.85 & 0.85 & 0.85 & 0.85 \\
\hline \multirow{2}{*}{$\begin{array}{l}\text { Compressive } \\
\text { strength, } \\
\text { fck }\left({\mathrm{N} / \mathrm{mm}^{2}}^{2}\right)\end{array}$} & 32.3 & 33.2 & 31.5 & 35.7 & 34.9 & 33.2 & 23.8 & 25.5 & 25.5 & 27.2 & 25.9 & 24.7 & 39.1 & 35.7 & 37.4 & 39.1 & 37.4 & 39.1 & 38.3 & 36.6 & 34.9 \\
\hline & \multicolumn{6}{|c|}{$\mathrm{fck}=33$} & \multicolumn{6}{|c|}{$\mathrm{fck}=25$} & \multicolumn{6}{|c|}{$\mathrm{fck}=38$} & \multicolumn{3}{|c|}{$f c k=37$} \\
\hline
\end{tabular}

\subsection{Design for the Reinforced Concrete Structures}

Based on the output obtained in Figure 8 shown that steel reinforcement bar provided at main middle beam/ span for the bottom bar is $2 T 16,2 T 20,2 T 25$ \& $3 T 32$ and the top bar is $2 T 16,2 T 20$ \& $2 \mathrm{~T} 25$. While, the steel reinforcement bar provided at continuous edge/ support for the top bar is $2 \mathrm{~T} 20,2 \mathrm{~T} 25$ \& $2 \mathrm{~T} 32$. But based on as built structures inspection, the existing size of bottom bar is $2 \mathrm{~T} 20$ and top bar is $2 \mathrm{~T} 12$ shown as Figure 9. By comparing existing and designed size steel reinforcement, the size of existing steel reinforcement was not enough to support the loading at the beam 2/A-D \& 2/F-I or 3/A-D \& 3/F-I. But the strength of existing concrete was enough. Thus, the defect was occurred because of the steel reinforcement bar. It could not be sustained the big loading that applied such as library. 


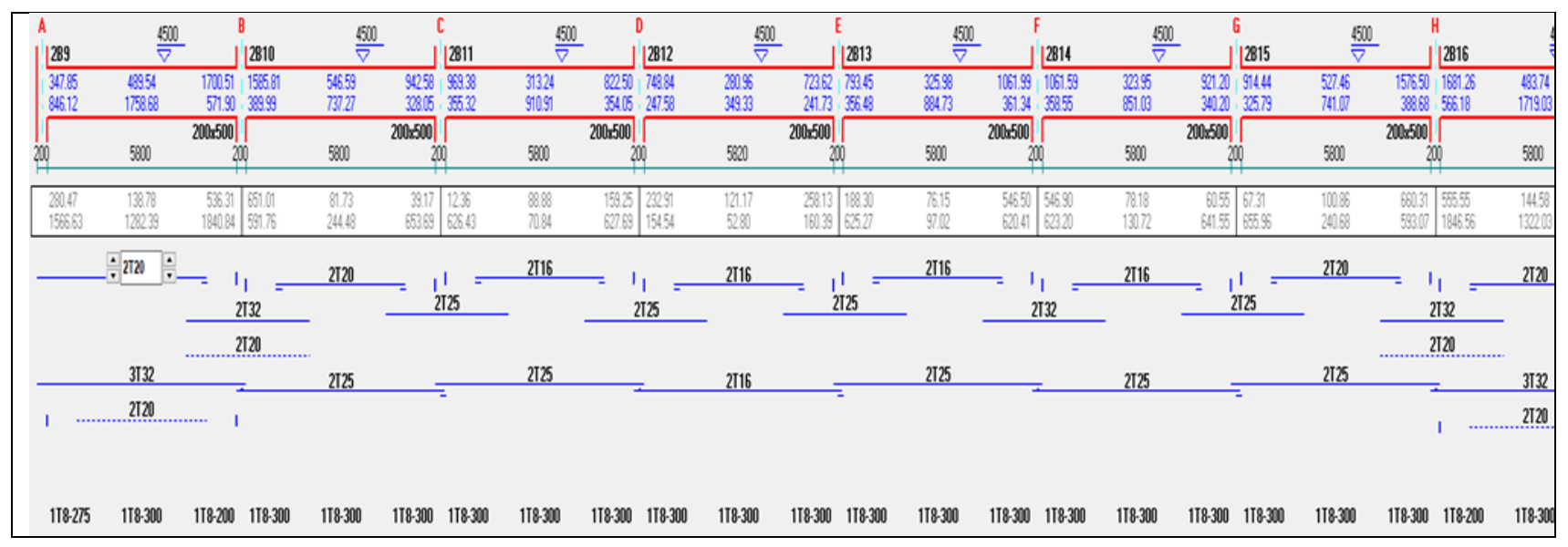

Fig. 8. Library Defect/ Crack Mapping at First Floor Plan (Soffit)

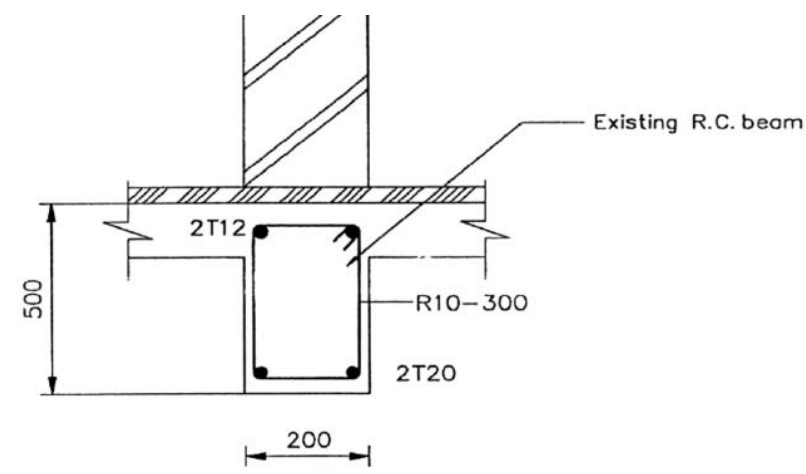

Fig. 9. Detail for the existing Reinforced Concrete beam

\section{Conclusions}

In conclusion, the concrete strength in library was in standard value which is $25 \mathrm{~N} / \mathrm{mm}^{2}$. Apart from that, in Orion beam reinforced concrete design, the standard size at middle span of bottom bar and top bar were $2 \mathrm{~T} 25$ and $2 \mathrm{~T} 16$ respectively. But the existing size of bottom bar and top bar were only $2 \mathrm{~T} 20$ and $2 \mathrm{~T} 12$ respectively. Regarding to the comparison, the size of existing steel reinforcement was too small compare to Orion designed. Thus, the defect was occurred is because of the steel reinforcement. In our opinion, there were many factors that affected the defect / crack at reinforced concrete structures. One of the factors is underestimate the loading to the library structures. Therefore, an engineer forensic required used holistic approaches to the evaluation, design and construction of building. For the recommendation, there are some actions that can be taken to overcome the structure defect issue. This is because when we ignore this problem, structure defect, as time passes, it will become structure failure. If structure failure occurs, it will destroy the whole building even though human life will be affected. Hence, here we list down several ways to overcome this structure defect issue.

a) Structural repair work to the structure crack.

b) Structural strengthening work. 


\section{Acknowledgement}

We would like to acknowledge the support from our organisations: Politeknik Kuching Sarawak, JKR Sarawak and UiTM Sarawak. However, the contents of this work are solely the responsibility of the authors.

\section{References}

[1] Nama, Pooja, Ankush Jain, Rajat Srivastava, and Yash Bhatia. "Study on causes of cracks \& its preventive measures in concrete structures." International Journal of Engineering Research and Applications 5, no. 5 (2015): 119-123.

[2] Krishna, T. T., Subathra, S., Meikandaan, T. P. (2018). “An Experimental Study of Crack Patterns on Reinforced Concrete Beam." International Research Journal of Engineering and Technology, 5(3) (pp. 3195-3202).

[3] Mehndi, Syed Mohd, M. A. Khan, and S. Ahmad. "Causes and Evaluation of Cracks in Concrete Structures."." International Journal of Technical Research and Applications 2, no. 5 (2014): 29-33.

[4] Allam, Said M., Mohie S. Shoukry, Gehad E. Rashad, and Amal S. Hassan. "Crack width evaluation for flexural RC members." Alexandria engineering journal 51, no. 3 (2012): 211-220. https://doi.org/10.1016/i.aej.2012.05.001

[5] Suganthy, P., and R. Gajendran. "Case Study on Identification, Evaluation \& Repair of Cracks in Concrete Structures." International Journal of Engineering Technology, Management and Applied Sciences 5, no. 1 (2017).

[6] Ajagbe, W.O., and Ojedele, O. S. (2018). "Structural Investigation into the Causes of Cracks in Building and Solutions: A Case Study." American Journal of Engineering Research, 7(8) (pp. 152-160).

[7] Bhosale, D.S., (2013). "Forensic Inverstigation for Sustainability Issues in Structure." International Journal Of Scientific and Engineering Research, 4(5) (pp. 153-157).

[8] Pathan, K. M., Sayyad Wajed Ali, Shaikh Zubair, and Aasim Hasan Najmi. "A forensic view to structures' failure analysis." SSRG International Journal of Civil Engineering 2 (2015): 26-32.

[9] Lim, C. C., and Y. C. Chua. "Structural strengthening of a shop-house for use as a medical centre." In Concrete Repair, Rehabilitation and Retrofitting IV, pp. 127-127. CRC Press, 2015. https://doi.org/10.1201/b18972-82

[10] Agunwamba, J. C., and T. Adagba. "A comparative analysis of the rebound hammer and ultrasonic pulse velocity in testing concrete." Nigerian journal of Technology 31, no. 1 (2012): 31-39.

[11] Ju, Minkwan, Kyoungsoo Park, and Hongseob Oh. "Estimation of compressive strength of high strength concrete using non-destructive technique and concrete core strength." Applied Sciences 7, no. 12 (2017): 1249. https://doi.org/10.3390/app7121249

[12] Gupta, S. L. "Comparison of non-destructive and destructive testing on concrete: A review." Trends in Civil Engineering and its Architecture 3, no. 1 (2018): 351-357. https://doi.org/10.32474/TCEIA.2018.03.000154

[13] Fahjan, Y. M., J. Kubin, and M. T. Tan. "Nonlinear analysis methods for reinforced concrete buildings with shear walls." In 14th European Conference on Earthquake Engineering. 2010.

[14] Lucrédio, Daniel, Calebe de Paula Bianchini, Antonio Francisco Do Prado, Luis Carlos Trevelin, and Eduardo Santana de Almeida. "Orion-a component-based software engineering environment." Technology 3, no. 4 (2004). https://doi.org/10.5381/jot.2004.3.4.a4

[15] Lightfoot, Jay M. "Orion: A menu-driveri source code generator for end users." Journal of International Information Management 2, no. 2 (1993): 7.

[16] Ehiorobo, J. O., O. C. Izinyon, and R. O. Ogirigbo. "Measurement and Documentation for Structural Integrity Assessment of In-Service Building at Risk." TSO7E-Engineering Surveying (2013): 1-6638.

[17] Rivera, Jonathan P., Goran Josipovic, Emma Lejeune, Bismarck N. Luna, and Andrew S. Whittaker. "Automated Detection and Measurement of Cracks in Reinforced Concrete Components." ACl Structural Journal 112, no. 3 (2015). https://doi.org/10.14359/51687424

[18] Kiran, V.K., Mohandas, K. A., Abhishek T. V., Akhila, Arya, K.V., Jafsal M. A., and Greeshma. (2018). "Different Approaches to Crack Monitoring of Buildings using IOT." International Journal for Research in Applied Science \& Engineering Technology, 6(8) (pp. 438-448).

[19] Standard, British. "Structural use of concrete, part 1. Code of practice for design and construction." Sector Board for Building and Civil Engineering (1997).

[20] Walraven, J. C. "Eurocode 2: Design of concrete structures EN1992-1-1." In Symposium Eurocodes: Background and Applications, Brussels. 2008. 
[21] Mosley, William Henry, Ray Hulse, and John Henry Bungey. Reinforced concrete design: to Eurocode 2. Macmillan International Higher Education, 2012.

[22] BS 6399. "Loading for buildings-Part 1: code of practice for dead and imposed loads." (1996).

[23] Cornelius. (2019). "Design of Residential Buildings Using CSC Orion (Step by Step with Eurocode 2)." Enginnering Basic. Retrieved August 29, 2018, from https://engineeringbasic.com/design-of-residential-buildings-using-cscorion-step-by-step-with-eurocode-2/ 